\title{
Identification of Artistically Gifted Children in Visual Arts Teaching
}

\author{
Marija Brajčić', Dubravka Kuščević ${ }^{2}$ and Marta Pupić Bakrač \\ 'University of Split, Faculty of Humanities and Social Sciences, Department of Preschool \\ Education \\ 2University of Split, Faculty of Humanities and Social Sciences, Department of Teacher \\ Education \\ ${ }^{3}$ Elementary School Majstor Radovan in Trogir
}

\section{Abstract}

The aim of this research was to evaluate how teachers recognize younger pupils who are artistically gifted (in visual arts). The participants were 150 elementary school teachers ( $1^{\text {st }}$ to $4^{\text {th }}$ grade) from the Split-Dalmatia County and the DubrovnikNeretva County in Croatia. Their task was to answer the questions in the two-part questionnaire in a truthful manner.

The results showed that the participants were familiar with the characteristics by which they could recognize gifted children. There were also confirmed statistically significant differences in identifying younger gifted pupils, regarding the teachers' work experience and level of education. The more educated and less experienced teachers were less successful in identifying gifted pupils than their more experienced, but less educated colleagues. No significant influence of the rural or urban background was noticed. We concluded that experience was a relevant factor in identifying gifted pupils.

Key words: artistically gifted child; pupil; teacher; visual arts teaching.

\section{Introduction}

Every person has a set of capabilities and skills, but a few truly excel in any particular area. Gifted pupils possess above-average talents and skills. A gifted pupil is a serious responsibility for every person in his/her educational process.

The person responsible for recognizing talent and providing care and support has to be professionally and ethically competent, as well as competent for continually building skills necessary for this process. It is often thought that artistic giftedness 
is easily seen and that gifted individuals participate in special activities, workshops, etc., but it is not the case. Teachers and parents do recognize gifted children sooner or later, but there is a lack of action to encourage the development of their capabilities. Gifted children often stagnate and their abilities and skills do not develop. All kinds of gifted pupils, not just those with a gift for visual arts, need to participate in programs adequate for them.

Continuous high-quality education of teachers in this particular area is of utmost importance when it comes to gifted pupils, whether in visual arts or in something other than that. Giftedness is often a topic in scientific literature, which emphasizes the importance of early detection of gifted children. Crljen and Polić (2006) claim that even preschool institutions need to care for gifted children and their needs, basing the process on a personalized approach, even more if the abilities are detectable and identifiable. Karijašević (2013) similarly emphasizes the necessity of recognizing gifted pupils in the school system: "well-timed identification, high-quality educational process and a positive attitude in their environment are the key in working with these children" (Karijašević, 2013, p. 71). Koren (2013), summing up many scientific articles on this subject, emphasizes a solid theoretical and empirical base for practical activities in researching giftedness.

The subject of giftedness is generally well-researched, whereas the specific issues of giftedness in visual arts often get overlooked. Teaching visual arts, unlike most school subjects, is specific by its spotlight on individual creation. This makes the subject of giftedness even more challenging.

Taking into consideration a lack of knowledge on this particular subject, we wanted to research the teachers' ability to identify artistically gifted younger pupils and its connection to their work experience and place of employment (urban vs rural areas).

This is a presentation of research results about the teachers' ability to identify younger pupils with a gift for visual arts.

\section{Gift/Talent, Giftedness for Visual Arts, Identifying Gifted Younger Pupils in Teaching Visual Arts}

Giftedness in education is a term several centuries old. Cvetković-Lay cites Jan Amos Komensky, who lived in the $17^{\text {th }}$ century, as a proponent of the importance of talent and identification of gifted individuals. There are around 140 definitions of talent, and many approaches to its research exist (Cvetković-Lay, 2002). Many authors have participated in the discussion about giftedness, offering different viewpoints and insights (Adžić, 2011; Crljen, \& Polić, 2006; Duh \& Batič, 2003; Duh \& Lep, 2008; Heller, Crljen, \& Polić, 2006; George, 2005; Huzjak, 2006; Koren, 2013; Matrić \& Duh, 2015; Monks et al., 2000; Sekulić-Majurec, 1996; Walker, 2007). The term giftedness is often discussed, yet we have no definite, single answer to what it actually is. The broadest definition would imply a set of characteristics that make it possible for an individual to achieve superior, well above average results. A gifted child is born with an 
exceptional ability to master a certain area or skill. Terman determines giftedness as an exceptionally developed general intellectual ability (Winner, 2005), while Tanennbaum (2004) defines it as a productive creative ability.

Von Kraft and Semke consider it as follows: "Giftedness is an inborn aptitude and ability by which we explain why an individual excels in the scientific, practicaltechnical or artistic field" (Von Kraft \& Semke, 2008, p. 8).

A widely accepted model of defining the productive talent is the three-ring conception of giftedness (Renzulli \& Reis, 1985, as cited in Cvetković-Lay, 2002). This defines giftedness as a combination of creativity, above average ability, and task commitment. These three elements overlap in the area in which giftedness is manifested through different activities. The giftedness observed through research manifests itself when the combination described above is applied on a specific area of action. Renzulli \& Reis (1985) point out that children do not necessarily display all three elements, but would be considered gifted if they possessed a capacity for developing them later in life. This model contains a specific kind of motivation which, according to Renzulli, is the energy that a gifted child directs towards finishing a task (as cited in Koren, 1989).

The research of Clark and Zimmerman (1984) highlights misunderstandings and myths about gifted children as the reason for their disregard, and the root of these is a misunderstanding of the nature of visual arts. A wide-spread negative opinion paints the individuals gifted for visual arts as not needing any special education, their talent as being easily identifiable, not many children being actually gifted, artists being illadapted, socially awkward, and their creative production as not requiring high general intelligence (Čudina-Obradović, 1991).

Milbrath (as cited in Cukierkorn, 2008) claims that the children gifted in visual arts (in further text: artistically gifted) see the world differently. They code visual information more accurately and see the world rather as a set of shapes and visual characteristics than as a set of definitions. Milbrath also claims that average young children, while painting or drawing, show objects and the world as they see and understand them, without showing the actual visual characteristics of the world around us. Unlike them, gifted children show it realistically.

Clark and Zimmerman (2004, as cited in Winner, 2005) list the basic characteristics of artistically gifted children: well-developed drawing skills, high level of motivation, interest, and sharpness in detailing in the creative process. These children also go through the phases of artistic development much faster than average children (scribbling, random representation, trying to achieve an intentional likeness of object and drawing, simple pictures) (Winner, 2005). The behavior of artistically gifted individuals is based on the fast learning of artistic skills, language and techniques. Specific interests of these children lead to dedication to a certain artistic area and accumulation of knowledge related to it, while their intellectual functioning relies on an easy grasp of the basic artistic principles, comprehension of complex phenomena, high level of metacognitive knowledge and skills, and exceptional memorizing skills. 
Artistically gifted children, unlike their peers, show a larger range of subject choices, their imagination is well-developed, and their ideas abundant. They also use color and contrast more subtly, according to their technical skills in visual expression. The most important difference between an average artistic development and that of a gifted child lies in the following characteristics:

1. Artistically average children use learned schemes and shapes, artistically gifted children use the memorized details of a situation they witnessed.

2. Artistically gifted children sooner master artistic skills such as: achieving rotation, reduction, perspective, shadows, etc.

3. An artistically talented child is not only more capable for artistic expression, but also achieves realism in its drawing not only by shapes and details, but through showing a third dimension. They often decorate realistic drawings with details, where colors and shapes change to express different things. Although the ability to draw realistically may be the most impressive skill of artistically gifted children, their work also shows an exceptional non-figurative ability to design, shape, and color. The realism is visible due to their ability to observe and remember visual details and complete the structure.

Artistically gifted individuals have a very well-developed spatial ability expressed through several interconnected abilities: sharp eye for details, also known as the visual discrimination of details, shades, images, visual memory, coupled with the ability to envision images with accurate details and the ability to revive them in thought and expression, and a refined hand-to-eye coordination. These characteristics represent an "ability of visual thought". Children who have them are exceptionally able to see, remember, evoke and reshape visual imagery. Visual-spatial aspects are of utmost importance: sensitivity to composing, organizing and mastering the language of visual arts - all of these develop through experiencing, practicing, observing objects in a new light, and they finally crystallize as a sense for harmony.

Gardner (1983) believes that artistic giftedness cannot be understood fully unless we take into consideration the factor of "feeling" - an artistic feeling achieved by working and learning, which represents the ability to transfer from the manifested and observed to the symbolic and abstract, to see "under the surface" of things. That exact feeling for harmony is another important factor in artistic giftedness: the ability to aesthetically evaluate. Although it is the hardest to define, measure, and study directly, it is what gives a specific attribute to a work of art (Čudina-Obradović, 1991). Expert identification serves to establish whether the recognized signals are truly the signs of a superior ability, and to estimate whether the child in question could benefit from a systematic intense program of development, or that kind of program would be inappropriate, forced and possibly damaging (Čudina-Obradović, 1991). In the process of establishing giftedness, it is necessary to define who is responsible for identifying it, with which methods and techniques and why. 
The process of discovering artistically gifted pupils includes the process of making systematic observations, providing systematic supervision and documenting all this. To identify a gifted pupil means to see the permanent and important behavioral patterns and shapes that are different from the behavior of his/her peers.

The most common ways to identify gifted individuals are the teacher's observations, different identification lists, the evaluations of works, as well as the evaluations and opinions of affirmed artists. Identification lists contain the basic characteristics of artistically gifted children in the shape of statements. The following examples are statements taken from a list used for identifying gifted pupils.

According to Vlah (2000), artistically gifted children show a wider range in subject choices, have a larger artistic vocabulary, are significantly more artistically developed than their peers, have an unusually vivid imagination, and are more competent to show a movement in a picture. They outdo average children in conscious efforts of grouping objects and people, are more competent in achieving subtlety in choosing color and contrasting, are aware of possibilities and limits of individual artistic media, and are ready to explore new materials for artistic expression. In addition, they are more willing and able to widen their interests for new, challenging subjects and contents, their total perception is more visually oriented and their observation skills are more precise, they are more able to interact efficiently between the visual observation and memory. Unlike average children, who like a solitary artistic activity, gifted children prefer explanations and teaching, are more sensitive to observing unusual objects, shapes and subjects, and are more influenced by an unusual artist's approach (Vlah, 2000).

The teacher's role is of extreme importance for detecting artistically gifted children. The early signs of development are often overlooked. Teachers need to be aware that gifted children have special educational needs. Artistically gifted individuals should use educational institutions with added contents, solve challenging tasks successfully, and participate in school programs that encourage the overall development, as well as individually create and explore (Jurasić, 2013).

\section{Method}

\section{Research Aim, Tasks and Hypotheses}

The aim of this research was to gain insight into the teachers' factual knowledge and ability to identify artistically gifted younger pupils. The tasks for reaching this aim were the following:

1. To question how how familiar the teachers are with the characteristics of gifted pupils.

2. To establish whether there is a difference between the teachers' recognition of artistically gifted younger pupils in relation to their work experience.

3. To establish whether there is a difference between the teachers' recognition of artistically gifted younger pupils in relation to the teachers' place of employment. 
According to the aim and tasks, the following hypotheses were formulated:

$\mathrm{H1}$ : Most teachers are familiar with the characteristics of artistically gifted younger pupils.

H2: Teachers with more work experience are better at identifying artistically gifted pupils.

H3: Teachers who work in urban areas are better at recognizing artistically gifted younger pupils than those working in rural areas.

\section{Sample and Research Method}

The sample consisted of 150 elementary school teachers ( $1^{\text {st }}$ to $4^{\text {th }}$ grade) from the Split-Dalmatia County and the Dubrovnik-Neretva County in Croatia. Sample analysis showed that $50 \%$ of the teachers had two years of college education, $39 \%$ of them had four years, and $11 \%$ of them had five years. The structure of the sample in relation to the independent variables is shown in Table 1 . The research was conducted in the second semester of academic year 2014/2015, and the data were collected directly from the research participants, i.e. the questionnaire was given to some teachers after they had finished their daily classes. The selection of teachers was random and participation was anonymous and voluntary. The participants were informed about the research aim and they were asked to be truthful when answering the questions.

Table 1

Sample structure in relation to independent variables

\begin{tabular}{llcc}
\hline Independent variables & Categories & $\mathrm{N}$ & $\mathrm{f}(\%)$ \\
\hline place of employment & rural area & 41 & 27 \\
& urban area & 109 & 73 \\
work experience & up to 5 years & 24 & 16 \\
& 6 to 11 years & 17 & 12 \\
& 12 to 17 years & 15 & 10 \\
& 18 to 23 years & 24 & 16 \\
& 24 to 29 years & 23 & 15 \\
education & more than 30 years & 47 & 31 \\
& two years of college & 75 & 50 \\
& 4 years of college & 59 & 39 \\
& 5 years of college & 16 & 11 \\
\hline
\end{tabular}

\section{Research Instrument and Procedure}

The instrument was an anonymous questionnaire in two parts, designed especially for the current research. The first part was designed to collect general information (place of employment, work experience, education), representing independent variables. The participants circled the answers that described them.

The second part consisted of 21 statements, representing the characteristics of artistically gifted children. The participants were offered the indicative behavioral patterns of artistically gifted pupils connected to creativity, motivation, initiative, selfreliance, visual perception, knowledge and use of visual language. 
The method used was the Likert scale, with the options to assess agreement or disagreement on a 1-5 scale (1 - I disagree completely, 2 - I mostly disagree, 3 I do not know, 4 - I mostly agree, 5 - I agree completely). The questionnaire was constructed especially for this research, but some practical instructions for recognizing artistically gifted pupils were used in statement formulations (Koren, 1989), as well as the official 2006 Croatian National Curriculum for elementary education. The statistical method used in this research is t-test.

\section{Results}

The first task of our research aimed to determine how familiar the teachers were with the characteristics of artistically gifted pupils. We started with the following hypothesis:

H1: Most teachers are familiar with the characteristics of artistically gifted younger pupils.

We confirmed that the teachers did recognize artistically gifted pupils very well. Of all 150 teachers, not a single one gave a rating of neither 1 nor 2 (disagreement) to any of the 21 statements offered.

Table 2

Teachers' knowledge about the characteristics of gifted students

\begin{tabular}{|c|c|c|c|c|c|c|c|c|c|c|}
\hline \multirow{2}{*}{$\begin{array}{c}\text { Statements } \\
1 .\end{array}$} & \multirow{2}{*}{$\begin{array}{c}\begin{array}{c}\text { I do not } \\
\text { agree }\end{array} \\
0 \%\end{array}$} & \multirow{2}{*}{$\begin{array}{c}\begin{array}{c}\text { I mostly } \\
\text { disagree }\end{array} \\
0 \%\end{array}$} & \multicolumn{2}{|c|}{$\begin{array}{l}\text { I don't } \\
\text { know } \\
\mathrm{p} / \mathrm{n}\end{array}$} & \multicolumn{2}{|c|}{$\begin{array}{l}\text { I mostly } \\
\text { agree } \\
\mathrm{p} / \mathrm{n}\end{array}$} & \multicolumn{2}{|c|}{$\begin{array}{c}\text { I completely } \\
\text { agree } \\
\mathrm{p} / \mathrm{n}\end{array}$} & \multicolumn{2}{|c|}{$\begin{array}{l}\text { Total } \\
\mathrm{p} / \mathrm{n}\end{array}$} \\
\hline & & & $6 \%$ & 9 & $9 \%$ & 13 & $85 \%$ & 128 & $100 \%$ & 150 \\
\hline 2. & $0 \%$ & $0 \%$ & $4 \%$ & 6 & $11 \%$ & 16 & $85 \%$ & 128 & $100 \%$ & 150 \\
\hline 3. & $0 \%$ & $0 \%$ & $3 \%$ & 5 & $7 \%$ & 10 & $90 \%$ & 135 & $100 \%$ & 150 \\
\hline 4. & $0 \%$ & $0 \%$ & $4 \%$ & 6 & $10 \%$ & 15 & $86 \%$ & 129 & $100 \%$ & 150 \\
\hline 5. & $0 \%$ & $0 \%$ & $10 \%$ & 15 & $20 \%$ & 30 & $70 \%$ & 105 & $100 \%$ & 150 \\
\hline 6. & $0 \%$ & $0 \%$ & $7 \%$ & 10 & $11 \%$ & 17 & $82 \%$ & 123 & $100 \%$ & 150 \\
\hline 7. & $0 \%$ & $0 \%$ & $10 \%$ & 15 & $12 \%$ & 18 & $78 \%$ & 117 & $100 \%$ & 150 \\
\hline 8. & $0 \%$ & $0 \%$ & $8 \%$ & 12 & $14 \%$ & 21 & $78 \%$ & 117 & $100 \%$ & 150 \\
\hline 9. & $0 \%$ & $0 \%$ & $13 \%$ & 19 & $17 \%$ & 26 & $70 \%$ & 105 & $100 \%$ & 150 \\
\hline 10. & $0 \%$ & $0 \%$ & $9 \%$ & 14 & $10 \%$ & 15 & $81 \%$ & 121 & $100 \%$ & 150 \\
\hline 11. & $0 \%$ & $0 \%$ & $16 \%$ & 24 & $14 \%$ & 21 & $70 \%$ & 105 & $100 \%$ & 150 \\
\hline 12. & $0 \%$ & $0 \%$ & $2 \%$ & 3 & $6 \%$ & 9 & $92 \%$ & 138 & $100 \%$ & 150 \\
\hline 13. & $0 \%$ & $0 \%$ & $10 \%$ & 15 & $12 \%$ & 18 & $78 \%$ & 117 & $100 \%$ & 150 \\
\hline 14. & $0 \%$ & $0 \%$ & $9 \%$ & 13 & $10 \%$ & 15 & $81 \%$ & 122 & $100 \%$ & 150 \\
\hline 15. & $0 \%$ & $0 \%$ & $4 \%$ & 6 & $6 \%$ & 9 & $90 \%$ & 135 & $100 \%$ & 150 \\
\hline 16. & $0 \%$ & $0 \%$ & $3 \%$ & 5 & $7 \%$ & 10 & $90 \%$ & 135 & $100 \%$ & 150 \\
\hline 17. & $0 \%$ & $0 \%$ & $4 \%$ & 6 & $17 \%$ & 26 & $79 \%$ & 118 & $100 \%$ & 150 \\
\hline 18. & $0 \%$ & $0 \%$ & $6 \%$ & 9 & $15 \%$ & 22 & $79 \%$ & 118 & $100 \%$ & 150 \\
\hline 19. & $0 \%$ & $0 \%$ & $7 \%$ & 10 & $12 \%$ & 18 & $81 \%$ & 122 & $100 \%$ & 150 \\
\hline 20. & $0 \%$ & $0 \%$ & $20 \%$ & 30 & $8 \%$ & 12 & $72 \%$ & 108 & $100 \%$ & 150 \\
\hline 21. & $0 \%$ & $0 \%$ & $10 \%$ & 15 & $18 \%$ & 27 & $72 \%$ & 108 & $100 \%$ & 150 \\
\hline
\end{tabular}

The statement by which the teachers most often identified gifted pupils was listed as number 12 (Artistically gifted children are often motivated for a long time and engaged 
in artistic processes). Of all the participants, $92 \%$ recognized this characteristic as the key. Artistically gifted children are highly self-motivated, occupy themselves with the activity in question, and concentrate deeply while working, which is easily observable.

The next highest-rated statements are number 3 (Artistically gifted children have a well-developed imagination and a large number of artistic ideas), number 15 (Artistically gifted children are interested in the figurative and abstract forms of artistic creation) and number 16 (Artistically gifted children are spontaneously conscious of composition). Of all the participating teachers, $90 \%$ identified artistically gifted children as being imaginative and possessing many artistic ideas. Artistically gifted individuals approach each work in their own way. Their works are highly original and imaginative. They also achieve balance and harmony when using individual visual elements and their relations, e.g. composition.

Statement number 4 (Artistically gifted children are more capable of showing movement and profile in images) was also ranked highly, as $86 \%$ of the teachers recognized the artistically gifted according to this characteristic. Artistically gifted pupils truly show this at the very beginning of their education. They often draw classmates in profile, or enjoy drawing the moving objects (cars, runners, animals etc.).

Statements number 1 (Artistically gifted children choose from a wider range of subjects) and 2 (Artistically gifted children use a richer artistic language and notice composition elements better) had an agreement of $85 \%$, which made them highly rated, too. Artistically gifted pupils show different subjects easily, which differentiates their works from those of their peers. They have no fear in showing various subjects; they find that task challenging and fun. They also use an artistic vocabulary more often than their average peers; they learn it quickly and understand its meaning.

Statement number 6 (Artistically gifted children use colors and their contrasts in a subtler way) was recognized by $82 \%$ of the participants. Artistically gifted pupils have a better feeling for color and color creation. They show independence in using vivid colors and rich impressions.

Statements 10, 14 and 19 were recognized by $81 \%$ of the participants (Artistically gifted children have the outstanding abilities to observe and memorize visual details and the whole structure; They observe the visual works of art with a keen interest; They are able to give themselves an artistic task and complete it). Artistically gifted children create drawings full of details and have exceptional visual memory. Visiting museums delights them, giving them the opportunity to observe the works of art.

Statements/characteristics of behavior described under 17 (Artistically gifted children easily switch from one artistic medium to another) and 18 (Artistically gifted children enjoy solving difficult artistic tasks) were recognized by $79 \%$ of the participants.

The characteristics of gifted pupils, listed under 7,8 and 12 (Artistically gifted children exceed the average ones in conscious attempts to group objects and people; They possess a great technical skill in artistic expression; Artistically gifted children are often motivated for a long time and engaged in artistic processes), were recognized somewhat less, by $78 \%$ of the participants. 
Artistically gifted children manipulate the visual imagery to express their thoughts and ideas, as well as their tendency to organize. They also have an aversion to the ending of visual arts classes, always wanting more.

The least recognized characteristics of artistically gifted children were under numbers 5 (They lead when working in groups), 9 (They often take notes by drawing) and 11 (They are more capable of an interaction between visual observation and visual memory). The result of $70 \%$ shows that the teachers noticed these characteristics less successfully than the rest. They obviously do not think that the artistically gifted take on a leadership role when working in groups. They do not notice taking notes by drawing because they usually do not look for that behavior. The artistically gifted pupils often mark homework, school trips and other significant events with a symbol or a small drawing, but the teachers usually pay no attention to it.

The least recognized characteristics, by $72 \%$ of the teachers, were those listed under 20 (Artistically gifted children tolerate difficulties in the artistic process) and 21 (Artistically gifted children like to be taught and have things explained during artistic activities). The reason may be that the artistically gifted are so occupied by their work that they look disinterested in anything else.

The results of this research show that the total of 150 elementary school teachers from the Split-Dalmatia County and the Dubrovnik-Neretva County in Croatia do recognize artistically gifted pupils, being rather familiar with their characteristics. The lowest individual result in identifying artistically gifted pupils was 59\%, and the highest individual result was $98 \%$, which indicates that a successful identification process of artistically gifted pupils takes place in schools.

Table 3

The ability to identify artistically gifted pupils

\begin{tabular}{lcccc}
\hline & M & SD & N & $t(149)$ \\
\hline $\begin{array}{l}\text { Teachers } \\
p>0.05\end{array}$ & 84.06 & 8.24 & 150 & 4.95 \\
\hline
\end{tabular}

The second task was aimed to discover whether the teachers differed in recognizing artistically gifted younger children in regard to their work experience. We had assumed that $\mathrm{H} 2$ would be confirmed: Teachers with more work experience are better at identifying artistically gifted pupils.

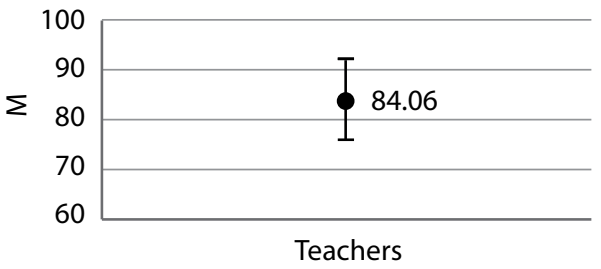

Figure 1. The ability to identify artistically gifted pupils 
To test the second hypothesis, a t-test was used. Mean is 84.06 , and the standard deviation is 8.25 (Figure 1). The value of the t-test is the following: $t(149)=4.9 p$ $>0.05$ (Table 3 ). The probability of accidental mistake is less than $5 \%$, so we cannot consider it statistically significant (with a risk of 5\%). The results show a statistically significant difference in identifying gifted students with reference to work experience. The results show that the teachers with longer work experience recognized artistically gifted children better (Table 4).

Table 4

Differences in identifying artistically gifted pupils in relation to teachers' work experience

\begin{tabular}{lcccc}
\hline & M & SD & N & SEM \\
\hline Shorter work experience & 79.3793 & 8.16889 & 58 & 1.07263 \\
Longer work experience & 86.9785 & 6.86671 & 92 & .71204 \\
\hline
\end{tabular}

Constant scientific progress brings along new knowledge almost daily, which influences everyone, including teachers. These processes influence formal education. Education of adult students is both formal and informal, as well as self-education (especially in scientific educational content). Education is, as Rajić and Lapat (2010) claim, an important factor of social progress and individual development of each person in modern society. The faculties of teacher education and the Croatian Education and Teacher Training Agency conduct the activities related to permanent teacher education. Pastuović (2008) defines permanent education as a lasting process, including the enrichment of the skills already attained with new knowledge. Teachers with more work experience care about their permanent education through seminars and workshops (making them more aware of the importance of their own education) and read scientific literature. All of these things affect their ability to recognize artistically gifted children, which confirms experience as a positive factor and makes the results of the research match the initial hypothesis.

H3: Teachers who work in urban areas are better at recognizing artistically gifted younger pupils than those working in rural areas.

To test the third hypothesis, a t-test was used again. The value of the t-test is the following: $\mathrm{t}(149)=-6.144, \mathrm{p}<0.05$. The probability of accidental mistake is less than $5 \%$, so we cannot consider it statistically significant (with a risk of 5\%). The standard deviation is 4.55629 for the participants from the urban areas, and for the participants from the rural areas it is 8.53042 . The results (Table 5) show no statistically significant difference in identifying gifted students in relation to the place of employment. The results show that the teachers in both rural and urban areas recognized artistically gifted children equally well.

The hypothesis presuming a statistically significant difference in identifying gifted pupils with reference to the teachers' place of employment was not confirmed, so it was rejected. 
Table 5

Differences in identifying artistically gifted pupils in relation to the place of teachers' employment

\begin{tabular}{lcccc}
\hline Teachers & $\mathrm{M}$ & $\mathrm{SD}$ & $\mathrm{N}$ & $\mathrm{SEM}$ \\
\hline urban areas & 89.1220 & 4.55629 & 109 & .71157 \\
rural areas & 82.1727 & 8.53042 & 41 & .81334 \\
\hline
\end{tabular}

\section{Conclusion}

The research led us to the conclusion that the teachers were quite familiar with the characteristics of artistically gifted pupils of a younger age. The teachers, especially those with more work experience, did identify gifted pupils successfully. It was also established that the place of employment did not influence the ability to identify gifted pupils.

Even though the teachers identify artistically gifted pupils successfully, a problem arises. After being identified, gifted pupils do not receive an approach designed to give them the ability to develop their potential. They are recognized and identified, but the process usually ends there, leaving them to themselves. It is of utmost importance that teachers, after recognizing gifted pupils, include them in programs or workshops to better stimulate their development.

An adequate approach to children that would encourage their gifts requires teacher competences within visual arts teaching. When we discuss the right approach to gifted pupils, we need to propagate the importance of education, expert-led programs and workshops for them, which would be organized in schools or as extracurricular activities.

\section{References}

Adžić, D. (2011). Darovitost i rad s darovitim učenicima - kako teoriju prenijeti u praksu. Život $i$ škola časopis za teoriju i praksu odgoja i obrazovanja, LVII(25), 171-184.

Crljen, M., \& Polić, R. (2006). Briga za nadarenu djecu. Metodički ogledi, 13(1), 137-147.

Cvetković-Lay, J. (2002). Darovito je, što ću sa sobom?. Zagreb: Alinea.

Cukierkorn, J. R. (2008). Arts Education for Gifted Learners. United States of America: Prufrock Press Inc.

Čudina-Obradović, M. (1991). Nadarenost - razumijevanje, prepoznavanje, razvijanje. Zagreb: Školska knjiga.

Duh, M., \& Batič, J. (2003). Problematika identifikacije likovnih talentov ob vstopu v osnovno šolo. In M. Blažič (Ed.), Nadarjeni. Izkoriščen ali prezrt potencial: zbornik (pp. 149-157). Novo Mesto: Slovensko združenje za nadarjene.

Duh, M., \& Lep, K. (2008). Evaluation of Artistically Gifted Pupils in Primary School. Journal of Elementary Education, 1( 3-4), 95-105.

Gardner, H. (1983). Frames of mind: The theory of multiple intelligence. New York: Basic Books. 
George, D. (2005). Obrazovanje darovitih: kako identificirati i obrazovati darovite i talentirane učenike. Zagreb: Educa.

Heller, K. A., Monks, F. J., Sternberg, R. J., \& Subotnik, R. (2000). International Handbook of Giftedness and Talent. Oxford: Elsevier Science Ltd.

Huzjak, M. (2006). Darovitost, talent i kreativnost u odgojnom procesu. Odgojne znanosti, $8(11), 232-238$.

Jurasić, A. (2013). Osobine darovite djece. Retrieved from www.math.uniri.hr/ ajurasic/ pred2.pdf

Koren, I. (1989). Kako prepoznati i identificirati nadarenog učenika. Zagreb: Školske Novine.

Matrić, M., \& Duh, M. (2015). Creativity Among Gifted and Non-Gifted Students. The New Educational Review, 40(2), 247-259.

Sekulić-Majurec, A. (1995). Darovita djeca i obitelj: istine i zablude. Društvena istraživanja, časopis za opća društvena pitanja, 4(4/5), 551-561.

Tannenbaum, A. J. (1983). Gifted children: Psychological and educational perspectives. New York: Macmillan.

Vlah, N. (2000). Od šaranja do Picassa. Retrieved from http://www.zzjzpgz.hr/nzl/47/ picasso.htm

Von Krafte, T., \& Semke, E. (2008). Kako otkriti i potaknuti darovitost. Zagreb: Mozaik knjiga.

Walker, S. Y. (2007). Darovita djeca: vodič za roditelje i odgajatelje: kako razumjeti, podržati $i$ potaknuti vaše darovito dijete. Zagreb: Veble commerce.

Winner, E. (2005). Darovita djeca: mitovi i stvarnost. Zagreb: Lekenik, Ostvarenje.

\section{Marija Brajčić}

University of Split, Faculty of Humanities and Social Sciences, Department of Preschool Education

Teslina 12, 21000 Split, Croatia

mbrajcic@ffst.hr

\section{Dubravka Kuščević}

University of Split, Faculty of Humanities and Social Sciences,

Department of Techer Education

Teslina 12, 21000 Split, Croatia

kuscevic@ffst.hr

Marta Pupić Bakrač

Elementary school Majstor Radovan in Trogir

Dr. Franje Tuđmana 12, 21220 Trogir, Croatia

martabp@gmail.com 


\section{Attachment}

I. Circle!

\section{IDENTIFYING ARTISTICALLY GIFTED CHILDREN}

\begin{tabular}{|c|c|c|c|}
\hline Work experience in years & $\begin{array}{lllll}\text { a) } 0-5 & \text { b) } 6-11 & \text { c) } 12-17 & \text { d) } 18-23 & \text { e) }\end{array}$ & $4-30 \mathrm{f})$ & ore than 30 \\
\hline Length of college education in years & b) four + additional education & c) four & e) five \\
\hline Place of employment & b) urban area & & \\
\hline County & a) Dubrovnik-Neretva & & \\
\hline
\end{tabular}

II. Read each statement carefully and select one number as the answer. The meaning of numbers is as follows:

1 - I disagree completely, 2 - I mostly disagree, 3 - I do not know, 4 - I mostly agree, 5 - I agree completely

Please, select a single answer that best describes your opinion.

Artistically gifted children:

\begin{tabular}{|c|c|c|c|c|c|c|}
\hline & Statements & $\begin{array}{l}\text { I disagree } \\
\text { completely }\end{array}$ & $\begin{array}{l}\text { I mostly } \\
\text { disagree }\end{array}$ & $\begin{array}{l}\text { I do not } \\
\text { know }\end{array}$ & $\begin{array}{l}\text { I mostly } \\
\text { agree }\end{array}$ & $\begin{array}{l}\text { I agree } \\
\text { completely }\end{array}$ \\
\hline 1. & $\begin{array}{l}\text { Artistically gifted children choose from } \\
\text { a larger range of subjects. }\end{array}$ & 1 & 2 & 3 & 4 & 5 \\
\hline 2. & $\begin{array}{l}\text { Artistically gifted children use a } \\
\text { richer artistic language and notice } \\
\text { composition elements better. }\end{array}$ & 1 & 2 & 3 & 4 & 5 \\
\hline 3. & $\begin{array}{l}\text { Artistically gifted children have a well- } \\
\text { developed imagination and a large } \\
\text { number of artistic ideas. }\end{array}$ & 1 & 2 & 3 & 4 & 5 \\
\hline 4. & $\begin{array}{l}\text { Artistically gifted children are more } \\
\text { capable of showing movement and } \\
\text { profile in images. }\end{array}$ & 1 & 2 & 3 & 4 & 5 \\
\hline 5. & They lead when working in groups. & 1 & 2 & 3 & 4 & 5 \\
\hline 6. & $\begin{array}{l}\text { Artistically gifted children use colors } \\
\text { and their contrasts in a subtler way. }\end{array}$ & 1 & 2 & 3 & 4 & 5 \\
\hline 7. & $\begin{array}{l}\text { Artistically gifted children exceed the } \\
\text { average ones in conscious attempts to } \\
\text { group objects and people. }\end{array}$ & 1 & 2 & 3 & 4 & 5 \\
\hline 8. & $\begin{array}{l}\text { They possess a great technical skill in } \\
\text { artistic expression. }\end{array}$ & 1 & 2 & 3 & 4 & 5 \\
\hline 9. & They often take notes by drawing. & 1 & 2 & 3 & 4 & 5 \\
\hline 10. & $\begin{array}{l}\text { Artistically gifted children have } \\
\text { outstanding abilities of observing and } \\
\text { memorizing visual details and the } \\
\text { whole structure. }\end{array}$ & 1 & 2 & 3 & 4 & 5 \\
\hline 11. & $\begin{array}{l}\text { They are more capable of an } \\
\text { interaction between visual observation } \\
\text { and visual memory. }\end{array}$ & 1 & 2 & 3 & 4 & 5 \\
\hline
\end{tabular}


Statements

I disagree I mostly I do not Imostly Iagree

completely disagree know agree completely

Artistically gifted children are often

12. motivated for a long time and engaged in artistic processes.

They are self-critical in evaluating

13. their own work, leaning towards perfectionism.

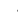

1

$$
2
$$

3

4

5

14. They observe the visual works of art with a keen interest.

$1-2$

Artistically gifted children are

15. interested in the figurative and abstract forms of artistic creation.

Artistically gifted children are

16. spontaneously conscious of composition.

2

3

4

5

Artistically gifted children easily switch

17. from one artistic medium to another.

18. Artistically gifted children enjoy

18. solving difficult artistic tasks.

19. They are able to give themselves an artistic task and complete it.

20. Artistically gifted children tolerate difficulties in the artistic process.

Artistically gifted children like to be

21. taught and have things explained during artistic activities.

$\begin{array}{llll}2 & 3 & 4 & 5\end{array}$

$\begin{array}{lllll}1 & 2 & 3 & 4 & 5 \\ 1 & 2 & 3 & 4 & 5 \\ 1 & 2 & 3 & 4 & 5 \\ 1 & 2 & 3 & 4 & 5 \\ 1 & 2 & 3 & 4 & 5 \\ 1 & 2 & 3 & 4 & 5\end{array}$




\section{Identifikacija likovno nadarene djece u nastavi likovne kulture}

\section{Sažetak}

Cilj ovog rada bio je istražiti koliko učitelji prepoznaju likovno nadarene učenike mlađe školske dobi. U istraživanju je sudjelovalo 150 učitelja razredne nastave iz Splitsko-dalmatinske i Dubrovačko-neretvanske županije u Hrvatskoj. Zadatak učiteljica bio je iskreno odgovoriti na anketna pitanja vezana uz karakteristike likovno nadarenog djeteta.

Rezultati su pokazali kako su učitelji upoznati s karakteristikama likovno nadarene djece. Također, utvrdili smo da postoji statistički značajna razlika u identificiranju likovno nadarenih učenika mlađe školske dobi sobzirom na trajanje radnog staža. Naime, mlađe sudionice s manje radnog iskustva slabije identificiraju likovno nadarene učenike od starijih učiteljica s više iskustva i manje obrazovanja. Nije uočen značajan utjecaj mjesta stanovanja u identificiranju likovno nadarenih učenika mlađe školske dobi. Zaključili smo da je iskustvo bitan faktor u identifikaciji likovno nadarenih učenika.

Ključne riječi: likovno nadareno dijete; nastava likovne kulture; učenik; učitelj.

\section{Uvod}

Svaki čovjek ima određene sposobnosti i vještine, ali samo su kod nekih različite sposobnosti i vještine odlično izražene. Iznimno izražene sposobnosti i vještine posjeduju nadareni učenici. Nadareni učenik velika je odgovornost za sve koji sudjeluju u kvalitetnim odgojno-obrazovnim aktivnostima.

Briga za nadarenu djecu i razvoj dječje nadarenosti autonomni je odgojni cilj, ali i uvjet opstanka svih kulturnih zajednica. Briga za nadarene pojedince podiže standard i kvalitetu samog društva. Iznimno je važno da se nadareno dijete što prije identificira i da podrška i briga budu kontinuirane i zastupljene već u ranom djetetovu odgoju i obrazovanju.

U prepoznavanju različitih oblika nadarenosti i mogućnosti pružanja brige nadarenim pojedincima nužno je biti stručno i etički osposobljen te se stalno usavršavati. Iako je uvriježeno mišljenje da se likovna nadarenost vrlo lako uočava i da se likovno nadareni pojedinci stalno uključuju u razne radionice, to ipak nije tako. Učitelji, a i roditelji prije ili kasnije prepoznaju likovno nadareno dijete, međutim, 
često se ništa ne poduzima kako bi likovno nadarena djeca uspješno razvila svoje sposobnosti. Tako likovno nadarena djeca ostanu zakinuta i ne razvijaju svoje sposobnosti i vještine, što nipošto nije poželjno.

Kako bi likovno nadareni učenici, kao i svi ostali nadareni učenici, bili prepoznati i uključeni u program koji odgovara njihovoj nadarenosti, važna je dobra educiranost učitelja u tom području. Problematika nadarenosti dobro je zastupljena u znanstvenoj i stručnoj literaturi gdje se ističe važnost ranog detektiranja nadarene djece. U tom smislu Crljen, Polić (2006) navode kako je već u predškolskim ustanovama nužno voditi brigu o nadarenoj djeci i njihovim potrebama utemeljenim na osobnom pristupu tim više ako su navedene sposobnosti uočljive i otkrivene identifikacijskim postupkom. Slično i Karijašević (2013) ističe nužnost prepoznavanja nadarenih učenika u školskom odgojno-obrazovnom sustavu te navodi: „pravovremena identifikacija, kvalitetan odgojno-obrazovni rad, te pozitivan odnos sredine prema nadarenim osobama ključni su u cjelokupnom radu s ovom djecom" (Karijašević, 2013, str. 71). Sumirajući mnoge znanstvene članke napisane o toj problematici, Koren (2013) ističe kako postoji solidna teorijska i empirijska podloga za praktične aktivnosti u području istraživanja nadarenosti.

Problematika nadarenosti općenito je dobro istražena, a specifičnosti likovne nadarenosti pomalo su zanemarene. Likovna je nastava, za razliku od ostalih nastavnih predmeta, specifična po tome što djeca imaju kontinuiranu mogućnost samostalnog stvaralaštva. Zbog toga je tema nadarenosti još izazovnija u likovnom području.

S obzirom na to da u literaturi u vezi s tim nema odgovarajućih spoznaja, željeli smo, s obzirom na radno iskustvo i radno mjesto učitelja (selo-grad), istražiti osposobljenost učitelja u identificiranju likovno nadarenih učenika mlađe školske dobi, tj. utvrditi prepoznaju li učitelji karakteristike likovno nadarenih učenika.

\section{Nadarenost, likovna nadarenost, identifikacija likovno nadarene djece u nastavi likovne kulture}

Nadarenost kao pojam u području odgoja i obrazovanja pojavljuje se prije nekoliko stoljeća. Cvetković-Lay navodi kako već u 17. stoljeću Jan Amos Komensky ukazuje na darovite pojedince i važnost njihova identificiranja. Od tada postoji cijeli niz različitih pristupa i definicija nadarenosti, tako da se danas koristi oko 140 različitih definicija tog pojma. (Cvetković-Lay, 2002) Također, mnogi autori raspravljaju o tematici nadarenosti (Adžić, 2011; Crljen, i Polić, 2006; Duh i Batič, 2003; Duh i Lep, 2008; Heller, Crljen, i Polić, 2006; George, 2005; Huzjak, 2006; Koren, 2013; Matrić i Duh, 2015; Monks i sur., 2000; Sekulić-Majurec, 1996; Walker, 2007) ističući različite pristupe u navedenom području. Iako se s pojmom nadarenosti često susrećemo, ne postoji jedinstven odgovor na pitanje što je to nadarenost. Općenito rečeno, riječ je o sklopu osobina na osnovi kojih pojedinac postiže iznimno visok iznadprosječan uradak. Nadareno dijete rođeno je s iznimnom sposobnošću da svlada određeno područje. Terman navodi da je darovitost visoka opća intelektualna sposobnost (prema 
Winner, 2005), a prema Tanennbaumu darovitost predstavlja produktivnu kreativnu sposobnost (Tanennbaum, 2004).

Von Krafft i Semke definiraju darovitost na sljedeći način: „Darovitošću se smatra urođena sklonost i sposobnost kojom objašnjavamo zašto netko postiže natprosječne rezultate na znanstvenom, praktično-tehničkom ili umjetničkom području." (Von Krafft i Semke, 2008, str. 8)

U određivanju produktivne darovitosti prihvaćena je troprstenasta koncepcija nadarenosti. (Renzulli i Reis, 1985, prema Cvetković-Lay, 2002) Prema toj koncepciji darovitost uvjetuje splet triju sastavnica, a to su kreativnost, iznadprosječno razvijene sposobnosti i osobine ličnosti (posebno specifična motivacija za rad). Mjesto njihova međusobnog preklapanja tvori prostor u kojem se iskazuje nadarenost u specifičnim područjima aktivnosti. Dakle, istraživana nadarenost manifestira se kada se kombinacija tih triju faktora primijeni na specifično područje djelovanja. Renzulli ističe da djeca ne moraju nužno pokazivati sve tri karakteristike nadarenosti, ali će biti smatrana nadarenom ako imaju kapacitet da te osobine poslije u životu razviju. U ovom modelu naznačen je poseban vid motivacije koji po Renzulliu predstavlja energiju koju nadareno dijete ulaže u izvršenju zadatka. (prema Koren, 1989)

Prema istraživanjima Clarka i Zimermana (1984) razlozi zanemarivanja likovno nadarenih leže u pogrešnim shvaćanjima i mitovima koji onemogućuju uspješan razvoj likovnih aktivnosti, a proizlaze iz krivih shvaćanja same prirode likovnih nadarenosti. Naime, zastupljeno je mišljenje da likovno nadareni pojedinci ne trebaju posebno likovno obrazovanje, kako je identifikacija likovno nadarenih jednostavna jer je njihov talent lako uočljiv, kako su sva djeca likovno nadarena, kako je samo malen broj djece stvarno likovno nadaren, kako su likovni umjetnici neprilagođeni, socijalno čudni i kako za likovno kreativnu produkciju nije potrebna visoka opća inteligencija. (Čudina-Obradović, 1991)

Milbrath (prema Cukierkorn, 2008) navodi da djeca koja su nadarena u likovnoj umjetnosti zapravo vide svijet drugačije. Naime, likovno nadarena djeca kodiraju vizualne informacije točnije i vide svijet manje u smislu pojmova, a više u smislu oblika i vizualnih obilježja. Milibtrath tvrdi da kada prosječna manja djeca crtaju ili slikaju, onda ona pokazuju objekte i svijet onako kako ga ona razumiju i vide, te ne prikazuju prave vizualne karakteristike našeg svijeta. Za razliku od njih likovno nadarena djeca prikazuju svijet realno. (Cukierkorn, 2008)

$\mathrm{Na}$ temelju istraživanja Clarka i Zimmermana iz 2004. godine navode se osnovne karakteristike likovno nadarene djece, a to su dobro razvijene vještine crtanja, visoka motivacija, interes, izoštrenost i uporaba detalja u stvaranju (prema Winner, 2005). Također, likovno nadarena djeca faze likovnog razvoja (faza šaranja, faza slučajne reprezentacije, faza pokušaja postizanja namjerne sličnosti predmeta $i$ crteža, faza nastanka jednostavnih slika) prolaze mnogo brže od prosječne djece (prema Winner, 2005). Ponašanje likovno nadarenih pojedinaca temelji se na brzom učenju likovnih vještina, jezika i tehnika. Specifični interesi te djece usmjereni su na 
posvećenost određenom umjetničkom području i sakupljanje znanja iz tog područja, a intelektualno funkcioniranje temelji se na lakom shvaćanju osnovnih likovnih načela, razumijevanju složenih pojava, visokom metakognitivnom znanju i vještinama, kao i osobitom pamćenju.

Likovno nadarena djeca, za razliku od svojih vršnjaka, pokazuju veći raspon u izboru likovnih tema, imaju razvijenu maštu i raspolažu velikim brojem likovnih ideja. Također, suptilnije se koriste bojama i njihovim kontrastima te posjeduju izvrsnu tehničku vještinu u likovnom izražavanju. Bitna razlika između uobičajenog likovnog razvoja i razvoja likovno darovitog djeteta leži u tri važne karakteristike:

1. likovno prosječna djeca barataju naučenim likovnim shemama i oblicima; likovno nadareni oslanjaju se na zapamćene pojedinosti neke doživljene situacije,

2. likovno nadareni ranije ovladaju likovnim vještinama prikazivanja kao što su postizanje rotacije, skraćenja, perspektiva, sjena,

3. likovno nadareno dijete nije sposobnije samo u likovnom izražavanju; realizam u crtežima ne postižu samo crtanjem različitih oblika i detalja, već i prikazivanjem treće dimenzije. Često realistične crteže likovno nadarena djeca obogaćuju dekorativnim obilježjima pa tako boje koriste na izražajan način te se boje i likovi domišljato i neprekidno mijenjaju. Iako sposobnost realističnog crtanja može biti najtipičnija i najdojmljivija karakteristika likovno nadarenih, u njima se pojavljuje iznimna, nefigurativna sposobnost u dizajnu, obliku i boji. Realizam se očituje u crtežima zbog izrazite sposobnosti zapažanja i pamćenja vizualnih detalja i cjelovite strukture (prema Winner, 2005).

Likovno nadareni pojedinci imaju iznimno dobru razvijenu vizualno spacijalnu sposobnost koja je izražena putem nekoliko međusobno povezanih sposobnosti, a to su: vrlo izoštreno zapažanje, tzv. vizualna diskriminacija detalja, nijansi, slika, vizualna memorija, odnosno sposobnost predočavanja u svijesti slika s točno reproduciranim detaljima i mogućnost da se ožive i iskoriste u mišljenju i izražavanju i naposljetku fina koordinacija ruke i oka. Te tri navedene sposobnosti predstavljaju „sposobnosti vizualnog mišljenja“. Likovno nadarena djeca imaju izvrsne sposobnosti da vide, pamte, dočaraju i preoblikuju vizualne slike. Vrlo su važni aspekti vizualno-spacijalne sposobnosti - osjetliivost za kompoziciju, organizaciju, ovladavanje likovnim jezikom, koji se razvijaju iskustvom, vježbom, gledanjem stvari drugačije, a kristaliziraju se kao osjećaj za harmoniju.

Međutim Gardner (1983) smatra da likovnu nadarenost ne možemo u potpunosti razumjeti ako ne uzmemo u obzir upravo taj čimbenik koji on naziva "feeling“ likovni osjećaj koji se stječe radom i učenjem, a predstavlja sposobnost da se iz pojavnosti i opaženog prijeđe na simbolično i apstrahirano, da se stvari vide drugačije, „ispod površine“. Upravo taj osjećaj za sklad predstavlja još jedan važan čimbenik umjetničke nadarenosti, a to je sposobnost estetskog procjenjivanja. Iako je taj faktor najteže definirati, mjeriti i direktno proučavati, to je ono što pojedinom djelu likovnog stvaralaštva daje specifično obilježje (Čudina-Obradović, 1991). Identifikacijom 
se stručno utvrđuje jesu li opaženi i prepoznati signali doista znakovi razvijenije sposobnosti i hoće li dijete zaista napredovati od sustavnog i intenzivnog programa razvoja, ili bi takav program bio neprimjeren dječjim sposobnostima, neusklađen s motivacijom, nametnut i možda zbog toga štetan (Čudina-Obradović, 1991). U postupku utvrđivanja nadarenosti potrebno je precizirati tko identificira nadarenost, kojim metodama i tehnikama, s kojim ciljem i zašto.

U procesu otkrivanja likovno nadarenih učenika uključeni su postupci sistemskog opažanja, praćenja i evidentiranja. Otkriti likovno nadarenog učenika znači uočiti trajne i općevrijedne oblike njegova ponašanja koji ga značajno izdvajaju od takvog ponašanja njegovih vršnjaka.

Najčešći načini identifikacije likovno nadarenih su učiteljevo opažanje, različiti popisi za identifikaciju, procjene radova, procjene i mišljenje afirmiranih umjetnika. Popisi za identifikaciju navode osnovne karakteristike likovno nadarene djece u obliku tvrdnji. Slijede primjeri tvrdnji iz popisa za identifikaciju likovno nadarenih.

Likovno nadarena djeca pokazuju veći raspon u izboru tema, imaju veći likovni rječnik, znatno su više likovno razvijena od svojih vršnjaka, imaju neobično razvijenu maštu, sposobnija su u prikazivanju pokreta na slici, nadmašuju prosječnu djecu u svjesnom pokušaju grupiranja objekata i ljudi, sposobnija su u postizanju suptilnosti u upotrebi boje, kontrasta, svjesna su mogućnosti i ograničenja pojedinih likovnih medija, spremna su istraživati nove materijale za likovno izražavanje, spremnija su i sposobnija proširiti interes za nove, izazovne teme i sadržaje, totalna percepcija im je više vizualno orijentirana i zapažanje preciznije, sposobnija su za djelotvorniju interakciju između vizualne opservacije i memorije, suprotno od prosječnog djeteta koje voli osamljenu likovnu aktivnost, ona traže objašnjenja i poučavanje, osjetljivija su za neobične predmete, oblike i teme i na njih više utječe neobičan pristup umjetnika (Vlah, 2000).

Uloga učitelja od iznimne je važnosti za detektiranje likovno nadarenih. Često se događa da se ignoriraju rani pokazatelji razvoja dječjih likovnih sposobnosti. Učitelji moraju biti svjesni da likovno nadarena djeca imaju posebne obrazovne potrebe. Likovno nadareni trebaju raditi u obogaćenim odgojno-obrazovnim ustanovama, rješavati izazovne zadatke i postizati uspjeh, sudjelovati u školskim programima koji potiču cjelokupan razvoj, kao i stalno samostalno stvarati i istraživati (Jurasić, 2013).

\section{Metodologija istraživanja}

\section{Cilj, zadatci i hipoteze istraživanja}

Cilj istraživanja bio je istražiti informiranost učitelja, odnosno sposobnost učitelja u identificiranju likovno nadarenih učenika mlađe školske dobi. Kako bi se ostvario navedeni cilj, postavljeni su ovi zadatci istraživanja:

1. Ispitati u kojoj su mjeri učitelji upoznati s karakteristikama likovno darovitih učenika. 
2. Utvrditi razlikuju li se učitelji u poznavanju likovno nadarene djece mlađe školske dobi s obzirom na radno iskustvo.

3. Utvrditi razlikuju li se učitelji u poznavanju likovno nadarene djece mlađe školske dobi s obzirom na mjesto stanovanja.

U skladu s navedenim ciljem i zadatcima postavljene su sljedeće hipoteze istraživanja: H1: Učitelji su u velikom broju upoznati skarakteristikama likovno nadarenih učenika

H2: Učitelji s dužim stažem bolje identificiraju likovno nadarene učenike.

H3: Učitelji koji rade u gradu bolje identificiraju likovno nadarene učenika od učitelja koji rade na selu.

\section{Uzorak i postupak istraživanja}

Uzorak ovog istraživanja uključuje ukupno 150 učiteljica razredne nastave iz Splitsko-dalmatinske i Dubrovačko-neretvanske županije u Republici Hrvatskoj. Od toga je $50 \%$ učiteljica završilo fakultet koji je trajao dvije godine, njih $39 \%$ završilo je fakultet koji je trajao 4 godine, a njih $11 \%$ fakultet koji je trajao 5 godina. Struktura uzorka s obzirom na nezavisne varijable prikazana je u tablici 1. Istraživanje je provedeno u drugom polugodištu šk. god. 2014./ 2015. pa su podatci prikupljeni izravno od sudionika istraživanja, odnosno upitnik je podijeljen učiteljima nasumično nakon nastave u njihovim školama. Izbor učitelja bio je slučajan. Sudjelovanje u istraživanju bilo je anonimno i dobrovoljno. Sudionici su bili ukratko upoznati sa svrhom istraživanja, zajamčena im je anonimnost podataka te su zamoljeni da iskreno odgovaraju na pitanja.

Tablica 1

\section{Instrument istraživanja}

U istraživanju se koristio anonimni anketni upitnik, posebno izrađen za potrebe ovog istraživanja, koji se sastojao od dva dijela. Prvim dijelom od sudionika su prikupljeni tzv. opći podatci važni za provedeno istraživanje (mjesto stanovanja, trajanje radnog staža) koji predstavljaju nezavisne varijable, i to na način da su među ponuđenim odgovorima sudionici zaokružili one koji se odnose na njih.

Drugi dio upitnika sastojao se od 21 tvrdnje koje predstavljaju karakteristike likovno nadarene djece. Ispitanicima su bile ponuđene indikativne osobine ponašanja likovno nadarenih učenika vezane uz kreativnost, motivaciju, inicijativnost, samostalnost, vizualnu percepciju, poznavanje i upotrebu likovnog jezika.

U upitniku se koristila Likertova skala od pet stupnjeva, a mogućnosti odgovora varirale su od ( 1 - uopće se ne slažem s navedenom tvrdnjom) do (5 - u potpunosti se slažem s navedenom tvrdnjom). Upitnik je posebno konstruiran za ovo istraživanje. Međutim u oblikovanju tvrdnji koristile su se praktične upute za nastavnike u prepoznavanju likovno nadarenih učenika (Koren, 1989) i Nastavni plan i program za osnovnu školu iz 2006. godine koji je na snazi u Republici Hrvatskoj. Statističke metode koje su se koristile u ovom istraživanju bile su t-test i standardna devijacija. 


\section{Rezultati istraživanja}

U prvom zadatku istraživanja željeli smo ispitati u kojoj su mjeri učitelji upoznati s karakteristikama likovno darovitih učenika.

Pri tome smo pošli od hipoteze H1: Učiteljice su u velikom broju upoznate s karakteristikama likovno nadarenih učenika.

Utvrdili smo da učiteljice uistinu vrlo dobro prepoznaju likovno nadarene učenike. Naime, od svih 150 anketiranih učiteljica u 21 tvrdnji nijedan odgovor nije bio ocijenjen ocjenom 1 i 2, odnosno potpunim neslaganjem s navedenom tvrdnjom.

\section{Tablica 2}

Tvrdnja po kojoj učiteljice najviše prepoznaju likovno nadarene učenike jest tvrdnja broj 12 (Likovno nadarena djeca često su vrlo dugo motivirana i angažirana u likovnom radu.). Naime, $92 \%$ učiteljica prepoznalo je tu karakteristiku kao ključnu. Likovno nadarena djeca imaju izraženu samoinicijativu te su uronjena u umjetničku aktivnost i duboko koncentrirana dok rade, što je lako uočljivo. Stoga učiteljice bez poteškoća uočavaju tu karakteristiku likovno nadarene djece.

Sljedeće najviše ocijenjene tvrdnje su tvrdnja broj 3 (Likovno nadarena djeca imaju razvijenu maštu i raspolažu velikim brojem likovnih ideja.), zatim broj 15 (Likovno nadarena djeca pokazuju interes za figurativne i apstraktne oblike likovnog rada.) i tvrdnja broj 16 (Likovno nadarena djeca posjeduju spontanu svijest za kompoziciju.). Čak $90 \%$ učiteljica identificira likovno nadarenu djecu kao maštovitu i s velikim brojem likovnih ideja. Likovno nadareni pojedinci svakom radu pristupaju na svoj način. Radovi su izrazito originalni i maštoviti. Također, likovno nadareni postižu sklad pri uporabi pojedinih likovnih elemenata i njihovih odnosa, odnosno kompozicije.

Tvrdnja broj 4 (Likovno nadarena djeca sposobnija su za prikazivanje pokreta i prikaza profila na slici.) također je visoko rangirana jer $86 \%$ učiteljica prepoznaje likovno nadarene prema toj karakteristici. Likovno nadareni učenici zaista pokazuju tu osobinu ponašanja u vrlo ranom školovanju. Često crtaju svoje prijatelje iz razreda prikazujući njihov profil ili uživaju crtajući predmete u pokretu (automobile, maratonce, životinje itd.)

Prva (Likovno nadarena djeca prikazuju veći raspon u izboru likovnih tema.) i druga tvrdnja (Likovno nadarena djeca raspolažu bogatijim likovnim jezikom i bolje uočavaju kompozicijske elemente.) ostvarile su postotak od $85 \%$, što je također visoko ocijenjena karakteristika likovno nadarenih učenika. Likovno nadareni učenici prikazuju različite teme olako pa se njihovi radovi po raznovrsnosti uvelike razlikuju od radova njihovih vršnjaka. Nemaju straha u prikazivanju bilo koje teme. Štoviše, to im je izazovno i zabavno. Također, koriste se likovnim rječnikom mnogo češće od svojih vršnjaka, brzo ga uče i razumiju.

Tvrdnju broj 6 (Likovno nadarena djeca suptilnije upotrebljavaju boje i njihove kontraste.) učiteljice prepoznaju u postotku od $82 \%$. Likovno nadareni učenici imaju osjećaj za boju i stvaranje boja. Pokazuju veliku neovisnost u primjeni živih boja i bogatih impresija. 
Tvrdnje pod brojem 10, 14 i 19 učitelji i uciiteljice prepoznaju u postotku od $81 \%$ (Likovno nadarena djeca imaju izrazite sposobnosti zapažanja i pamćenja vizualnih detalja i cjelovite strukture; Likovne umjetničke tvorevine promatraju s izrazitim interesom; Sposobna su da sama sebi zadaju likovni zadatak i da ga dovedu do kraja.). Likovno nadarena djeca uvijek stvaraju crteže prepune detalja te imaju iznimnu vizualnu memoriju. Odlazak u muzej kod likovno nadarenih izaziva veliko oduševljenje jer uživaju u promatranju umjetničkih djela.

Tvrdnje, odnosno osobine ponašanja pod brojem 17 (Likovno nadarena djeca lako prelaze s jednog likovnog sredstva na drugo.) i 18 (Likovno nadarena djeca uživaju u rješavanju težih likovnih zadataka.) učitelji i učiteljice prepoznaju u postotku od $79 \%$.

Malo slabije prepoznate karakteristike likovno nadarenih učenika nalaze se u tvrdnjama broj 7, 9 i 12 (Likovno nadarena djeca nadmašuju prosječnu djecu u svjesnom pokušaju grupiranja objekata i ljudi; Posjeduju izvrsnu tehničku vještinu u likovnom izražavanju; Često su vrlo dugo motivirana $i$ angažirana u likovnom radu.). Učiteljice su prepoznale likovno nadarene učenike po tim osobinama ponašanja u postotku od $78 \%$.

Likovno nadarena djeca manipuliraju vizualnim predodžbama za izražavanje misli i ideja te imaju izrazitu sklonost organiziranju. Također, likovno nadarenim učenicima zbog duge motiviranosti i angažiranosti teško "pada" završetak sata likovne kulture jer uvijek žele još.

Najslabije prepoznate karakteristike likovno nadarene djece su one pod brojem 5 (U grupnim radovima vode glavnu riječ.) i 9 (Često prave zabilješke crtanjem.) i 11 (Sposobnija su za interakciju između vizualne opservacije i vizualne memorije.). Najmanji rezultat od $70 \%$ pokazuje da učiteljice najslabije uočavaju te karakteristike. Učiteljice očito ne smatraju da se likovno nadareni ističu kao vođe u grupnim radovima. A osobinu da često rade zabilješke crtanjem ne uočavaju jer ne prate takve osobine ponašanja. Likovno nadareni učenici često zabilježe svoju domaću zadaću pa i obavijesti za roditeljski sastanak, odlazak u kino ili kazalište nekim drugačijim znakom, manjim crtežom i sl., a učiteljice na to ne obraćaju pažnju.

Također, najmanje prepoznate karakteristike likovno nadarenih su one pod brojem 20 (Likovno nadarena djeca toleriraju teškoće tijekom likovnog stvaranja.) i 21 (Likovno nadarena djeca tijekom likovne aktivnosti vole objašnjenja i poučavanje.). Učiteljice prepoznaju te osobine ponašanja kod likovno nadarenih pojedinaca u postotku od $72 \%$. Možda razlog leži u tome da su likovno nadareni duboko koncentrirani u svom radu pa izgleda kao da ih ništa drugo ne zanima.

Rezultati ovog dijela istraživanja pokazuju da učiteljice iz Splitsko-dalmatinske i Dubrovačko-neretvanske županije u Republici Hrvatskoj uistinu vrlo uspješno identificiraju likovno nadarene učenike. Dakle, učiteljice su upoznate s karakteristikama likovno nadarenih. Minimalan pojedinačan rezultat u identificiranju likovno nadarenih je $59 \%$, a maksimalan $98 \%$, što ukazuje na uspješno identificiranje likovno nadarenih učenika u školama. Standardna devijacija iznosi 8,24802, što pokazuje da nema velikih odstupanja među odgovorima ispitanica. 


\section{Tablica 3}

Graf 1

U drugom istraživačkom zadatku željeli smo saznati razlikuju li se učitelji u poznavanju likovno nadarene djece mlađe školske dobi s obzirom na radno iskustvo u nastavi. Pretpostavili smo da će H2: Učitelji s dužim stažem bolje identificirati likovno nadarene učenike.

Kako bismo testirali drugu hipotezu, koristili smo se t-testom. Aritmetička sredina je 84,06, a standardna devijacija 8,25 (Graf 1). Vrijednost t-testa je sljedeća: $t$ (149) $=4,953 \mathrm{p}>0,05$. Vjerojatnost slučajne pogreške manja je od $5 \%$ pa razliku možemo proglasiti statistički značajnom (uz rizik od $5 \%$ ). Rezultati koje smo dobili ukazuju na postojanje statistički značajne razlike u identificiranju učenika s obzirom na staž. Dakle, dobiveni rezultati pokazuju da učitelji s dužim stažem bolje identificiraju likovno nadarene učenike od učitelja s kraćim radnim stažem (Tablica 4).

\section{Tablica 4}

Stalni napredak znanosti u području odgoja i obrazovanja gotovo svakodnevno donosi nova znanja koja utječu na sve sudionike tog procesa, pa time i na učitelje. Navedeni procesi svakako utječu na formalno obrazovanje. Obrazovanje odraslih uz formalno obrazovanje uključuje i neformalno obrazovanje, kao i samoobrazovanje posebno na stručnoobrazovnim sadržajima. Obrazovanje je, kao što ističu Rajić, i Lapat, u svim suvremenim društvima važan faktor društvenog napretka i individualnog razvoja svake osobe (Rajić, i Lapat, 2010). Stoga je permanentno obrazovanje dužnost dobro osposobljenog učitelja. Kao što je poznato, Agencija za odgoj i obrazovanje, a i Učiteljski fakulteti, vode vrlo intenzivnu aktivnost permanentnog obrazovanja učitelja. Kako navodi Pastuović permanentno obrazovanje predstavlja trajno usavršavanje ili, drugim riječima, održavanje osposobljenosti s novim spoznajama u nekom području (Pastuović, 2008). Učitelji s više radnog staža sigurno vode računa o svom permanentnom obrazovanju, više posjećuju seminare, radionice (svjesniji su važnosti svoje edukacije) te su više u kontaktu sa stručnom literaturom, što svakako utječe na njihova saznanja o likovno nadarenoj djeci. Na temelju toga smo zaključili kako je profesionalno iskustvo koje su stekli tijekom svog radnog staža važan faktor u prepoznavanju likovno nadarene djece. Rezultati su u skladu s postavljenom hipotezom.

H3: Učitelji koji rade u gradu bolje identificiraju likovno nadarene učenike od učitelja koji rade na selu.

Kako bismo testirali treću hipotezu, koristili smo se t-testom. Vrijednost t-testa je sljedeća: $\mathrm{t}(149)=-6,144, \mathrm{p}<0,05$. Vjerojatnost slučajne pogreške veća je od $5 \%$ pa razliku ne možemo proglasiti statistički značajnom (uz rizik od $5 \%$ ). Standardna devijacija iznosi 4,55629 za ispitanice iz grada, a za ispitanice iz sela iznosi 8,53042. Rezultati koji su dobiveni (Tablica 5) ne ukazuju na postojanje statistički značajne razlike $\mathrm{u}$ identificiranju učenika s obzirom na mjesto stanovanja. Dakle učiteljice i na 
selu i u gradu podjednako dobro prepoznaju likovno nadarenu djecu. Očekivali smo da će gradski učitelji bolje identificirati likovno nadarene učenike jer su im dostupniji izvori uz pomoć kojih se obrazuju, međutim iz rezultata je očito da se i seoski učitelji danas permanentno obrazuju.

Rezultati nisu u skladu s postavljenom hipotezom pa ju možemo odbaciti. Naime, nije potvrđena postavljena hipoteza prema kojoj postoji statistički značajna razlika u sposobnosti identificiranja likovno nadarenih učenika u razrednoj nastavi s obzirom na mjesto stanovanja.

Tablica 5

\section{Zaključak}

Iz provedenog istraživanja može se zaključiti kako su učitelji upoznati s karakteristikama likovno nadarenih učenika mlađe školske dobi. Učitelji uistinu, pogotovo oni s više godina radnog staža, vrlo uspješno identificiraju likovno nadarene učenike. Također se utvrdilo kako mjesto stanovanja ne utječe na sposobnost identificiranja likovno nadarenih učenika.

Iako učitelji uspješno identificiraju likovno nadarene učenike, problem je u tome što likovno nadareni učenici nakon identifikacije ostaju zakinuti za jedan drugačiji pristup radu koji bi im pružio mogućnost razvoja vlastitih potencijala. Naime sve ostane na tome da su likovno nadareni učenici prepoznati i identificirani. Nakon toga oni su prepušteni sami sebi. Upravo je zato važno, da ih učitelji, nakon što prepoznaju likovno nadarene učenike, uključe u odgovarajući program, odnosno likovne radionice kako bi se tako bolje potaknuo njihov razvoj.

Dakle, adekvatan pristup djeci u poticanju likovne nadarenosti zahtijeva kompetencije učitelja u okviru nastavnog predmeta Likovne kulture. Kada se bavimo likovno nadarenim učenicima, potrebno je istaknuti važnost edukacije, stručnih programa i radionica za likovno nadarene učenike koji bi se u školi odvijali u okviru izvannastavnih aktivnosti. 